\title{
The Distribution of Cytotoxic Necrotizing Factors (CNF-1, CNF-2, CNF-3) and Cytolethal Distending Toxins (CDT-1, CDT-2, CDT-3, CDT-4) in Escherichia coli Strains Isolated from Extraintestinal Infections and The Determination of Their Philogenetic Relationship by PFGE
}

Cansu ONLEN GUNERI ( $\nabla$ cansuonlen.guneri@sbu.edu.tr )

Saglik Bilimleri University https://orcid.org/0000-0002-6112-0693

Fatih KOKSAL

Cukurova Universitesi Tip Fakultesi

Suna KIZILYILDIRIM

Suleyman Demirel Universitesi

Basak BEDIR

Cukurova Universitesi Tip Fakultesi

Togrul Nagiyev

Cukurova Universitesi Tip Fakultesi

Research article

Keywords: CNF, CDT, ExPEC, PFGE

Posted Date: December 8th, 2020

DOl: https://doi.org/10.21203/rs.3.rs-120529/v1

License: (c) (i) This work is licensed under a Creative Commons Attribution 4.0 International License. Read Full License 


\section{Abstract}

Background: Determinants of extraintestinal infection in Escherichia coli (E. coli) remain unclear. Virulence factors making Extraintestinal pathogenic E. coli (ExPEC) different from other E. coli strains are the host cell adhesion, invasion, and two important factors/toxins, Cytotoxic Necrotizing Factor (CNF) and Cytolethal Distending Toxin (CDT) that are responsible for cell death. In the present study, prevalence of CNF-CDT genotypes was investigated in 645 E. colistrains isolated from patients. This prevalence was analyzed regarding clinical origins, phylogroups and putative phylogenetic relationships.

Results: At least one virulence gene identified for ExPEC was found in 156 (24\%) of 645 E. coli strains. $78,12,20$ of ExPEC strains contained cnf1, cnf2, cnf3, respectively. Genes of cdt1, cdt2, cdt3 and cdt4 were detected as 20, 4, 4, 4. Finally, two factors were detected cnf1-cnf3 ( $n=6)$, cnf1- cdt1 ( $n=4)$, cdt1-cdt4 $(n=4)$. These 156 strains were found to be distributed in 106 large clusters by Pulsed-Field Gel Electrophoresis (PFGE). Virulent ExPEC was primarily related to the groups B2 (60\%) and D (32\%).

Conclusions: The CNF gene family is believed to enhance colonization of E. coli especially in the urinary system and the genes of $E$. coli gene pool gain the ability to survive in new environments, such as the human urinary tract. The widespread diffusion of the CNF gene in E. coli helps to distinguish ExPEC from commensal strains and these genes may be used as specific marker for non-commensal $E$. coli. It was concluded that different strains of $E$. coli gained ExPEC properties by acquiring different virulence genes resulting in deletion and recombination mutations, and it was thought that the infections caused by these strains were more likely community-acquired rather than hospital-acquired. Furthermore, in this study, cnf2, cnf3, cdt1, cdt2, cdt3 and cdt4 genes were demonstrated in Turkey for the first time.

\section{Background}

Escherichia coli (E. coli) is one of the major elements of the human colon microflora. E. coli can easily transfer virulence and resistance genes from other flora bacteria in the intestinal flora. Some geno-serotypes of $E$. coli cause pathologies in the intestinal tract, ranging from simple secretory diarrhea pathologies to inflammatory diarrhea in the form of dysentery with mortality. However, their colonization in sterile areas in the body, outside of the intestinal system, is always considered to be the cause of clinical pathology. Extraintestinal Pathogenic $E$. coli (ExPEC) causes urinary tract infection, newborn meningitis, sepsis, osteomyelitis, pneumonia, surgical site infections and infections in other extraintestinal areas. Although infections caused by ExPEC have low morbidity, it is becoming an increasingly important endemic problem due to its fatal course and prolonged hospital stay. Important virulence mechanisms that distinguish ExPEC from other $E$. coli strains include adhesion, invasion, defect of host defense and direct intervention in host cellular functions by secreted effectors $(11,12)$. These effectors are composed of a functional toxin class disrupting cell cycle, the basic cell process of the host cell. Especially toxins-factors in E. coli species are defined under 2 classes: Rho-GTPase-targeting toxin class is cnf1cnf3 (Cytotoxic Necrotizing Factor) and cdt1-cdt4 (Cytolethal Distending Toxin), which is genotoxin. While CNFs promote DNA replication without cytokinesis, CDTs block mitosis $(13,14)$. These toxins-factors are encoded through mobile elements (island of pathogenicity, plasmids, bacteriophages, etc.) (15).

There have been a limited number of clinical-epidemiological studies revealing that ExPEC strains have different colonization and virulence factors and that polymorphism in genes encoding virulence factors affect the prognosis of the disease. 
The aim of our study was to investigate the prevalence of CNF-CDT and the relationship between the clinical picture and genotypes in E. coli strains with different clinical origins. Thus, it was to detect a specific marker for the diagnosis of non-commensal E. coli.

\section{Methods}

\section{Isolation and Identification}

A total of 645 clinical samples (i.e., blood, urine, bronchoalveolar lavage, sputum, and surgical wound) were collected from different clinics of Balcalı Hospital at Cukurova University and of Adana Regional Hospital, Turkey, between September 2014 and April 2016. These 645 ExPEC strains were isolated from 387 outpatients and 129 inpatients. Most of the specimens were urine (80\%) and most were taken from the polyclinics of urology and pediatric (Fig. 1-Figure 2). Other specimens taken in other medical units were wound, blood, sputum, aspirate, sterile body fluid, vagina and urosepsis (Fig. 1-Figure 2). The median age of patients with ExPEC was 45 years (range, new born to 82 years). While urine samples were obtained from 80 males and 442 females, other specimens including wound, blood etc. were obtained from 107 males and 16 females.

The samples were cultured on blood agar and Endo agar plates (Merck, Germany) at $37^{\circ} \mathrm{C}$ for 24 hours. The isolates were first evaluated by Gram staining to examine the morphology of colonies and biochemical test characteristics. Strains were confirmed phenotypically by the IMVIC test and genotypically by the PCR method in the gene region (uidA) encoding Beta-D-glucuronidase enzyme found structurally in E. coli (Fig. 3). E. coli isolates were kept at $-70{ }^{\circ} \mathrm{C}$ in broth containing $20 \%$ glycerol.

\section{DNA Extraction and PCR}

In all isolates, DNA extraction was performed mechanically with a Mickle cell disruptor (The Mickle Lab. Engineering Co. Ltd., Gamshall, Surrey, UK). The amplicons were obtained by PCR using previously published primers (Table 1) uidA, cnf1, cnf2, cnf3, cdt1, cdt2, cdt3, cdt4 and extracted DNA samples. PCR amplifications were performed in a thermal cycler.

The PCR amplification was carried out in a total volume of $25 \mu$ l. The PCR mixture was constructed as follows: $12.5 \mu \mathrm{l} \mathrm{PCR}$ master mix ( $1 \mathrm{x}$ without MgCl2, $4 \mu \mathrm{l} \mathrm{MgCl} 2(25 \mathrm{mM}), 1 \mu \mathrm{lNTP}(200 \mu \mathrm{M}$ each nucleotides), $1 \mu \mathrm{l}$ each primer, Taq DNA polymerase $0.2 \mu \mathrm{U}(5 \mathrm{U} / \mu \mathrm{l}$ ), template DNA $5 \mu \mathrm{l}$ (approximately $50 \mathrm{ng}$ ) and distilled water by completing to 25 microliters. The uidA gene and cdt1, cdt2 cdt3, cdt4 genes were amplified in a single PCR reaction in one tube. Multiplex PCR protocol was used to determine $\mathbf{c n f 1 , ~} \mathbf{c n f} \mathbf{2}, \mathbf{c n f} \mathbf{3}$ genes. The PCR processes were applied for the amplifications of toxin genes (Table 2). The PCR products were separated on $2 \%$ agarose gel for cdts and uidA, and on $1.8 \%$ agarose gel for cnfs. Then, they were monitored using a Kodak UV transilluminator (Kodak, New York, USA).

\section{Phylogenetic Classification}

E. coli strains belonged to four groups (A, b1, b2, D) based on the presence of the chuA and yjaA genes and the DNA fragment (TSPE4.C2) (Table 1) by multiplex PCR as previously defined (Table 2). The results allowed the isolates to be classified into any of the four major phylogenies (224).

\section{Xbal Pulsed field gel electrophoresis}


PFGE was performed to determine DNA profiles of CNFs-CDTs producing strains. In our study, we applied the protocol described in a previous study (10) for Klebsiella, E. coli, P.aeruginosa, Acinetobacter (KEPA), which are the most frequently isolated gram-negative bacilli from the clinical material. PFGE method was performed for the determination of the clonal association of ExPEC strains and as gold standard. Epidemiological relationships between strains were evaluated by studying the PFGE patterns of genomic DNA after restriction by Xbal. The XbalPFGE was performed as described in the previous study (10) (Fig. 4).

Table 1

Oligonucleotide primers used in the study

\begin{tabular}{|c|c|c|c|c|}
\hline Primer & Target gene & Primer sequence $\left(5^{\prime}-3^{\prime}\right)$ & $\begin{array}{l}\text { Fragment } \\
\text { size (bp) }\end{array}$ & Reference \\
\hline uidA & uidA-F & ATGCCAGTCCAGCGTTTTTGC & 102 & J. Abid, 2014 \\
\hline uidA & uidA-R & AAAGTGTGGGTCAATAATCAGGAAGTG & 102 & J. Abid, 2014 \\
\hline cnf1 & cnf1-F & GGGGGAAAGTACAGAAGAATTA & 1111 & Dubois et al.,2010 \\
\hline cnf1 & cnf1-R & TTGCCGTCCACTCTCACCAGT & 1111 & Dubois et al.,2010 \\
\hline cnf2 & cnf2-F & TATCATACGGCAGGAGGAAGCACC & 1240 & Dubois et al.,2010 \\
\hline cnf2 & cnf2-R & GTCACAATAGACAATAATTTTCCG & 1240 & Dubois et al.,2010 \\
\hline cnf3 & cnf3-F & TAACGTAATTAGCAAAGA & 757 & Dubois et al.,2010 \\
\hline cnf3 & cnf3-R & GTCTTCATTACTTACAGT & 757 & Dubois et al.,2010 \\
\hline cdt1 & cdt1-F & CAATAGTCGCCCACAGGA & 411 & Toth et al., 2003 \\
\hline cdt1 & cdt1-R & ATAATCAAGAACACCACCAC & 411 & Toth et al., 2003 \\
\hline cdt2 & cdt2-F & GAAAGTAAATGGAATATAAATGTCCG & 556 & Toth et al., 2003 \\
\hline cdt2 & cdt2-R & TTTGTGTTGCCGCCGCTGGTGAAA & 556 & Toth et al., 2003 \\
\hline cdt3 & cdt3-F & GAAAGTAAATGGAATATAAATGTCCG & 555 & Toth et al., 2003 \\
\hline cdt3 & cdt3-R & TTTGTGTCGGTGCAGCAGGGAAAA & 555 & Toth et al., 2003 \\
\hline cdt4 & cdt4-F & CCTGATGGTTCAGGAGGCTGGTTC & 350 & Toth et al., 2003 \\
\hline cdt4 & cdt4-R & TTGCTCCAGAATCTATACCT & 350 & Toth et al.,2003 \\
\hline chuA & chuA-F & GACGAACCA ACGGTCAGGAT & 279 & Clermont et al., 2010 \\
\hline chuA & chuA-R & TGCCGCCAGTACC AAAGACA & 279 & Clermont et al., 2010 \\
\hline yjaA & yjaA-F & TGAAGTGTCAGGAGACGCTG & 211 & Clermont et al., 2010 \\
\hline yjaA & yjaA-R & ATGGAGAATGCGTTCCTCAAC & 211 & Clermont et al., 2010 \\
\hline TspE4C2 & TspE4C2-F & GAGTAATGTCGGGGCATTCA & 152 & Clermont et al., 2010 \\
\hline TspE4C2 & TspE4C2-R & CGCGCCAACAAAGTATTACG & 152 & Clermont et al., 2010 \\
\hline
\end{tabular}


Table 2

Thermal cycles for eleven primers used in the study

\begin{tabular}{|llllll|}
\hline No & Step & uidA & cnfs & cdts & chuA, yjA, tspe4.c2 \\
\hline 1 & Initial denaturation & $94{ }^{\circ} \mathrm{C} / 5 \mathrm{~min}$. & $94{ }^{\circ} \mathrm{C} / 3 \mathrm{~min}$. & $94^{\circ} \mathrm{C} / 5 \mathrm{~min}$. & $94{ }^{\circ} \mathrm{C} / 5 \mathrm{~min}$. \\
\hline 2 & Denaturation & $94{ }^{\circ} \mathrm{C} / 30 \mathrm{sec}$. & $94^{\circ} \mathrm{C} / 1 \mathrm{~min}$. & $94^{\circ} \mathrm{C} / 1 \mathrm{~min}$. & $94{ }^{\circ} \mathrm{C} / 30 \mathrm{sec}$. \\
& Annealing & $63^{\circ} \mathrm{C} / 30 \mathrm{sec}$. & $60^{\circ} \mathrm{C} / 1 \mathrm{~min}$. & $60^{\circ} \mathrm{C} / 1 \mathrm{~min}$. & $60{ }^{\circ} \mathrm{C} / 30 \mathrm{sec}$. \\
\cline { 2 - 4 } & Extension & $72{ }^{\circ} \mathrm{C} / 1.5 \mathrm{~min}$. & $72{ }^{\circ} \mathrm{C} / 1 \mathrm{~min}$. & $72{ }^{\circ} \mathrm{C} / 1 \mathrm{~min}$. & $72{ }^{\circ} \mathrm{C} / 1.5 \mathrm{~min}$. \\
\hline 3 & Final extension & $72{ }^{\circ} \mathrm{C} / 5 \mathrm{~min}$. & $72{ }^{\circ} \mathrm{C} / 7 \mathrm{~min}$ & $72{ }^{\circ} \mathrm{C} / 10 \mathrm{~min}$ & $72{ }^{\circ} \mathrm{C} / 5 \mathrm{~min}$. \\
\hline
\end{tabular}

\section{Results}

In the period of three years, a total of 645 ExPEC strains were studied. 522 of the samples were urine, 54, 28, 21, 6, 12,3 and 1 of them were wound, blood, sputum, aspirate, sterile body fluid, vaginal and urosepsis, respectively (Fig. 1). In 156 (24\%) of the 645 clinical samples, at least 1 virulence gene-positive was found. One hundred

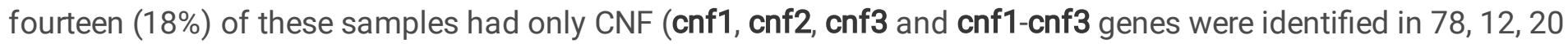
and 6 of the samples, respectively) (Fig. 5), thirty-six (5,4\%) had only CDT (cdt1, cdt2, cdt3, cdt4 and cdt1-cdt4 genes were identified in 20,4, 4,4 and 4 of the samples, respectively) (Fig. 6), and six (0,9\%) had both toxinsfactors) (Fig. 7) (Table 3).

According to the clinical origins of 645 ExPEC isolates, the distribution of virulence factors was found to be $3 \%$ in the EXPEC strains of the cdt gene family isolated from the urinary system and $15 \%$ in the non-urinary system isolates. While the rate of $\mathrm{Cnf}$ gene family was $20 \%$ in the urinary system, the ratio was $3 \%$ for the cdt gene family (Table 3). 
Table 3

Distribution of Toxin Genes in 645 ExPEC strains

\begin{tabular}{|c|c|c|c|c|c|c|c|c|c|c|}
\hline \multirow{2}{*}{$\begin{array}{l}\text { VFs } \\
(\%)\end{array}$} & \multirow{2}{*}{$\begin{array}{l}\text { All } \\
\text { isolates } \\
(n= \\
645) \\
n(\%)\end{array}$} & \multirow{2}{*}{$\begin{array}{l}\text { Urinary } \\
\text { system } \\
n=522 \\
(80)\end{array}$} & \multicolumn{8}{|c|}{ Non-urinary system } \\
\hline & & & $\begin{array}{l}\text { Total } \\
n= \\
123 \\
(20)\end{array}$ & $\begin{array}{l}\text { Wound } \\
(n= \\
54)\end{array}$ & $\begin{array}{l}\text { Blood } \\
(n= \\
28)\end{array}$ & $\begin{array}{l}\text { Sputum } \\
(n=21)\end{array}$ & $\begin{array}{l}\text { Aspirte } \\
(n=6)\end{array}$ & $\begin{array}{l}\text { Sterile } \\
\text { body } \\
\text { fluid } \\
(n= \\
12)\end{array}$ & $\begin{array}{l}\text { Urosepsis } \\
(n=3)\end{array}$ & $\begin{array}{l}\text { Vagen } \\
(n=1)\end{array}$ \\
\hline cnf1 & $78(12)$ & $68(13)$ & $10(8)$ & $3(5)$ & $\begin{array}{l}3 \\
(11)\end{array}$ & $3(14)$ & $1(16)$ & - & - & - \\
\hline cnf2 & $12(2)$ & $10(2)$ & $2(1,6)$ & $1(2)$ & $1(4)$ & - & - & - & - & - \\
\hline cnf3 & $20(3)$ & $16(3)$ & $4(3,2)$ & $2(4)$ & $1(4)$ & $1(5)$ & - & - & - & - \\
\hline $\begin{array}{l}\text { cnf1- } \\
\text { cnf3 }\end{array}$ & $6(0,9)$ & $5(1)$ & $1(0,8)$ & - & $1(4)$ & - & - & - & - & - \\
\hline $\begin{array}{l}\text { Total } \\
\text { cnfs }\end{array}$ & $\begin{array}{l}116 \\
(18)\end{array}$ & $97(20)$ & $17(13)$ & & & & & & & \\
\hline cdt1 & $20(3)$ & $12(2)$ & $8(7)$ & - & $1(4)$ & $2(10)$ & $2(32)$ & $2(16)$ & $1(33)$ & - \\
\hline cdt2 & $4(0,6)$ & $2(0,3)$ & $2(1,7)$ & $1(2)$ & $1(4)$ & - & - & - & - & - \\
\hline cdt3 & $4(0,6)$ & $2(0,3)$ & $2(1,7)$ & - & - & $1(5)$ & - & - & - & - \\
\hline cdt4 & $4(0,6)$ & $2(0,3)$ & $2(1,7)$ & $1(2)$ & - & - & $1(16)$ & - & - & - \\
\hline $\begin{array}{l}\text { cdt1- } \\
\text { cdt4 }\end{array}$ & $4(0,6)$ & $1(0,2)$ & $3(3,2)$ & $2(4)$ & $1(4)$ & - & $1(16)$ & - & - & - \\
\hline $\begin{array}{l}\text { Total } \\
\text { cdts }\end{array}$ & $36(5,4)$ & $19(3)$ & $\begin{array}{l}18 \\
(15)\end{array}$ & & & & & & & \\
\hline $\begin{array}{l}\text { cnf1- } \\
\text { cdt1 }\end{array}$ & $4(0,9)$ & $3(0,8)$ & $1(1,7)$ & $1(2)$ & - & - & - & - & - & - \\
\hline
\end{tabular}

In 156 E. coli isolates, at least one of whose virulence genes defined for ExPEC were positive and therefore can be identified as ExPEC (cnf1, cnf2, cnf3-cdt1, cdt2, cdt3, cdt4), the highest prevalence was cnf1 among the virulence genes with a rate of $50 \%+7.6 \%$ in binary combinations. This was followed by cdt 1 with a rate of $12.8 \%+2.5 \%$ in binary combinations (Table 4).

Table 4

Distribution of Toxin Genes in CDT and CNF positive 156 ExPEC strains

\begin{tabular}{|lllllllllll|}
\hline $\begin{array}{l}\text { Virulence } \\
\text { factor }\end{array}$ & cnf1 & cnf2 & cnf3 & $\begin{array}{l}\text { cnf1- } \\
\text { cnf3 }\end{array}$ & cdt1 & cdt2 & cdt3 & cdt4 & $\begin{array}{l}\text { cdt1- } \\
\text { cdt4 }\end{array}$ & $\begin{array}{l}\text { cnf1- } \\
\text { cdt1 }\end{array}$ \\
\hline $\begin{array}{l}\text { Total } \\
\text { (n=156) }\end{array}$ & 78 & 12 & 20 & 6 & 20 & 4 & 4 & 4 & 4 & 4 \\
\hline $\mathrm{n} /$ total & $78 / 156$ & $12 / 156$ & $20 / 156$ & $6 / 156$ & $20 / 156$ & $4 / 156$ & $4 / 156$ & $4 / 156$ & $4 / 156$ & $4 / 156$ \\
\hline$\%$ & 50 & 7,6 & 12,8 & 3,8 & 12,8 & 2,5 & 2,5 & 2,5 & 2,5 & 2,5 \\
\hline
\end{tabular}


In the distribution of virulence genes / gene combinations detected in these strains via the clinical materials from which the strains were isolated, it was observed that 121 (78\%) of 156 strains, where at least 1 virulence gene was positive, were associated with the urinary system, and the remaining 35 (22\%) were isolated from extra-intestinal urinary infection foci. The most common of the virulence genotypes in 121 clinical materials originating from the urinary system was the CNF gene family with a rate of $78 \%$. The CDT gene family was $17 \%$. In CNF-CDT positive isolates, it was $2 \%$. (Table 5 ).

While 68 of 78 cnf1 positive strains originated from urinary system, 10 of them were isolated from other extraintestinal infection foci. Similar rates were observed in cnf2 and cnf3. However, among the positive genes of cdt1, cdt2, cdt3, cdt4, only cdt1 proved superiority in the urinary system with a rate of $10 \%$, while cdt2, cdt3 and cdt4 were found in equal percentages. The cdtB gene family proved its superiority, especially in aspirated, sputum, peritoneal fluid, urosepsis and CSF material. The strains with at least 2 gene regions were found to be predominant in strains isolated from non-urinary tract infection. (Table 5).

Table 5

Distribution of factor-toxin genes of 156 ExPEC isolates by clinical origin / The virulence factor distributions in the urinary and non-urinary tract foci in CDT and CNF positive ExPEC strains

\begin{tabular}{|c|c|c|c|c|c|c|c|c|}
\hline \multirow{2}{*}{\multicolumn{2}{|c|}{$\begin{array}{l}\mathrm{n}(\%) \\
\text { Urinary system } \mathrm{n}= \\
121(78)\end{array}$}} & & \multicolumn{6}{|l|}{$\mathrm{n}(\%)$} \\
\hline & & & \multicolumn{6}{|c|}{ Non-urinary system $n=35$ (22) } \\
\hline $\begin{array}{l}\text { Isolates } \\
\text { VFs }\end{array}$ & $\begin{array}{l}\text { Urine } \\
(n=121)\end{array}$ & $\begin{array}{l}\text { Wound } \\
(n= \\
11)\end{array}$ & $\begin{array}{l}\text { Blood } \\
(n= \\
9)\end{array}$ & $\begin{array}{l}\text { Sputum } \\
(n=7)\end{array}$ & $\begin{array}{l}\text { Aspirate } \\
(n=5)\end{array}$ & $\begin{array}{l}\text { CSF } \\
(n= \\
1)\end{array}$ & $\begin{array}{l}\text { Peritoneal fluid } \\
(n=1)\end{array}$ & $\begin{array}{l}\text { Urosepsis } \\
(n=1)\end{array}$ \\
\hline cnf1 & $68(56)$ & $3(27)$ & $\begin{array}{l}3 \\
(33)\end{array}$ & $3(43)$ & $1(20)$ & - & - & - \\
\hline cnf2 & $10(8)$ & $1(9)$ & $\begin{array}{l}1 \\
(11)\end{array}$ & - & - & - & - & - \\
\hline cnf3 & $16(13)$ & $2(18)$ & $\begin{array}{l}1 \\
(11)\end{array}$ & $1(14)$ & - & - & - & - \\
\hline $\begin{array}{l}\text { cnf1- } \\
\text { cnf3 }\end{array}$ & $5(4)$ & - & $\begin{array}{l}1 \\
(11)\end{array}$ & - & - & - & - & - \\
\hline cdt1 & $12(10)$ & - & $\begin{array}{l}1 \\
(11)\end{array}$ & $2(29)$ & $2(40)$ & 1 & 1 & 1 \\
\hline cdt2 & $2(2)$ & $1(9)$ & $\begin{array}{l}1 \\
(11)\end{array}$ & - & - & - & - & - \\
\hline cdt3 & $2(2)$ & - & - & $1(14)$ & $1(20)$ & - & - & - \\
\hline cdt4 & $2(2)$ & $1(9)$ & - & - & $1(20)$ & - & - & - \\
\hline $\begin{array}{l}\text { cdt1- } \\
\text { cdt4 }\end{array}$ & $1(1)$ & $2(18)$ & $\begin{array}{l}1 \\
(11)\end{array}$ & - & - & - & - & - \\
\hline $\begin{array}{l}\text { cnf1- } \\
\text { cdt1 }\end{array}$ & $3(2)$ & $1(9)$ & - & - & - & - & - & - \\
\hline
\end{tabular}

Of the 156 ExPEC strains with at least one virulence gene, group b2 was the mostly associated with virulence with a rate of $60.8 \%$. This was followed by group D at a rate of $30.7 \%$. The rates of groups $A$ and b1 were $5.12 \%$ and 
It was observed that cnf1 was found to be significantly more frequent in the phylogroup b2 urinary tract strains than the phylogroup b2 non-urinary tract strains. While the same situation was valid for group $D$ as well, the opposite was the case in group b1, and it was more common in non-urinary system isolates (Table 6).

Table 6

Distribution of 156 ExPEC isolates virulence genes by phylogenetic group and clinical origin

\begin{tabular}{|c|c|c|c|c|c|}
\hline \multirow[t]{2}{*}{$\begin{array}{l}\text { Virulence } \\
\text { genes }\end{array}$} & \multirow{2}{*}{$\begin{array}{l}\text { No. }(\%) \text { of virulance } \\
\text { isolates }(n=156) \\
\text { Urinary/Others } \\
(n=121) /(n=35)\end{array}$} & \multicolumn{4}{|c|}{ No (\%) of isolates } \\
\hline & & $\begin{array}{l}\text { Group } A n=8 \\
(5,1)\end{array}$ & $\begin{array}{l}\text { Group b1 n } \\
=5(3,2)\end{array}$ & $\begin{array}{l}\text { Group b2 n = } \\
95(60)\end{array}$ & $\begin{array}{l}\text { Group D n = } \\
48(30)\end{array}$ \\
\hline Urinary/Others & Urinary/Others & Urinary/Others & Urinary/Others & & \\
\hline cnf1 & 68 (56) $10(29)$ & 00 & $03(60)$ & 37 (39) 4 (4) & $30(62) 4(8)$ \\
\hline cnf2 & 10 (8) 2 (6) & $3(37) 0$ & 00 & 7 (7) 2 (2) & 00 \\
\hline cnf3 & 16 (13) 4 (11) & $2(25) 2(25)$ & 00 & $12(13) 2(2)$ & $2(4) 0$ \\
\hline cdt1 & $12(10) 8$ (23) & 01 (13) & 00 & $12(13) 7(7)$ & 00 \\
\hline cdt2 & $2(2) 2(6)$ & 00 & 00 & 00 & 2 (4) 2 (4) \\
\hline cdt3 & $2(2) 2(6)$ & 00 & 00 & 00 & 2 (4) 2 (4) \\
\hline cdt4 & $2(2) 2(6)$ & 00 & $02(40)$ & $2(2) 0$ & 00 \\
\hline cnf1-cnf3 & 5 (4) 1 (3) & 00 & 00 & $5(5) 1$ & 00 \\
\hline cdt1-cdt4 & 1 (1) 3 (9) & 00 & 00 & 1 (5) 3 (3) & 00 \\
\hline cnf1-cdt1 & $2(2) 2(6)$ & 00 & 00 & 00 & $2(4) 2(4)$ \\
\hline
\end{tabular}

With the Xbal-PFGE method, 156 strains determined to be ExPEC based on 80\% similarity were collected in 106 clusters. It was revealed that four of the test strains $(Z 23, Z 25, Z 36, Z 38)$ had 5 members, 8 of them $(A, E, G, Z 60$, Z64, Z80, Z83 and Z88) had three members and 15 of them had two members (C, F, I, M, O, R, Z2, Z3, Z5, Z6, Z24, Z56, Z58, Z73 and Z76). In response to this, 81 strains were distributed into single-member clusters (Fig. 8).

The strains collected in a single-member cluster and in the same subset were determined to have different virulence factors. ExPEC isolates isolated from blood and urine clinical materials from the patients with urosepsis were found to be distributed in different clusters and had different virulence factors (for EXPEC strains, while cdt1 was positive in the blood sample (Z), it was negative in the urine sample in terms of any virulence factors (Z10)) using the PFGE method (Fig. 9).

\section{Discussion}

ExPEC-related infections, which have a wide range of disease spectrum from urinary tract infections to deadly bacteremia, have increased from 17.8-65.3\% in Turkey in the last 15 years (11). In this increase, it is important that ExPEC, which is under antibiotic pressure, gains new virulent properties with mobile genetic elements from different bacteria in order to survive under stress conditions. In addition to this, the use of irrational antibiotics is 
responsible for that increase. With a limited number of clinical-epidemiological studies; direct intervention to host cell functions, damage to epithelial cells and potent virulence factors that can lead to tissue pathologies such as stimulating the inflammatory response have been demonstrated by CNF-CDT positivity.

CDTs are genotoxins causing DNA damage in target cells. In our study, we found the prevalence of CDT as $6.3 \%$ (40/645) (Table 3). While this rate is similar to 6.8\% (222-223-9) having been reported in other studies; it is higher than the rate of $0.9 \%-2.5 \%(229-230)$. The variable prevalence of CDT genes can be explained by the fact that the test strains in our study and other studies were isolated from different extraintestinal infection areas.

CDT genes have been found to have a higher prevalence, especially in sepsis-related ExPEC strains compared to ExPEC strains isolated from other infection sites such as urinary tract infections (Table 3) (222-9). In our study, cdt gene was detected in $19(3 \%)$ of 522 strains isolated from patients with urinary system infections and in 18 (15\%) of 123 strains isolated from non-urinary system infections. The prevalence of urinary tract infections due to $E$. coli can also be explained by its being prone to easy colonization of the intestinal strains by invading into the urinary system through the neighborhood relationship and its capacity to easily create disease in the host under different stress factors without the need for an extra virulence factor. However, as a result of the disruption of the mucosal epithelial integrity of the mucosal epithelium in the intestinal lumen by CDT, which causes disruption of cellular integrity, EXPEC strains containing this factor easily translocate to the lamina propria prior to the intestines and then spreads to distant tissues with general circulation, making it possible to cause distant tissue infections especially sepsis. This may explain why the prevalence of CDT is high in ExPEC strains isolated from patients with sepsis and pneumonia. Sequence analysis of the $E$. colicdt operon indicated that this operon read cdtA, cdtB and cdtC; that is, it is necessary to read these 3 genes for the production of (231) active CDT. CdtB encodes enzymatically active protein subunits; polypeptides encoded by $c d t A$ and $c d t C$ are heterodimeric subunits required for binding of CDT to the target cell.

Four types of cdtB, which are defined as cdt1, cdt2, cdt3, cdt4, were identified in E. coli. (232). We detected all cdtB alleles in our study (Table 4). These findings revealed that in our ExPEC test strains, the prevalence of cdt1 and cdt4 was higher than the prevalence of cdt2 and cdt3 (Table 4). Similar to the other studies, the cdt1 and cdt4 alleles were found, but differently, the cdt2 and cdt3 alleles were not found $(222,223,234,229,238)$. These findings imply that the cdt 1 and cdt4 alleles of the CDT genes show very common and close homology and may have been derived from a common ancestor by phage transduction. Unlike these groups, it can be explained by many factors such as our finding that the cdt2 and cdt3 allo-types, namely the richness of our alleles, had local stress differences as well as the variety of our case groups in which we isolated the test strains.

On the other hand, CNF is the first toxin produced by the pathogen E. coli strains and reported to activate Rho GTPases dominantly. This toxin got this name because of its necrotizing effect on rabbit skin (134). We detected that $120(18.9 \%)$ of the $645 \mathrm{E}$. coli isolates included in the study carried at least one cnf allele (Table 3). In previous studies, this rate has been between $5-34 \%$ and it can be asserted that the rates are similar to each other considering the number of test strains (240-241-242), and deviations may stem from unreported patient characteristics.

cnf1 is responsible for tissue damage and impairs epithelial barrier function in tissue culture systems $(149,150)$ and affects the function of immune cells by blocking phagocytosis (151). cnf1 induces the expression of cyclooxygenase-2 (COX-2), activates nuclear factor-kappa B (NF-KB), increases cell mobility and inhibits apoptosis. Strong evidence has been obtained that cnf1 may play a role in cancer development (152-154). cnf1 delete 
mutants have been shown to have a lower potential to colonize the urinary system (148). In our study, 78 (65\%) of the necro-toxigenic $E$. coli isolates, detected as 120 , were $\mathbf{c n f 1}$ positive. On the other hand, cnf1 ratio was above $50 \%$ in 156 ExPEC isolates with positive virulence genes. In other studies, this rate has varied between $16.5 \%$ and $61.9 \%$ (143-243-244-229-222). In a study conducted in Turkey by Bozcal et al; cnf1 ratio was 12\% in ExPEC isolates isolated from blood samples (32). In our study, considering only blood samples, this rate was $11 \%$ (3/28) (Table 3) and it can be stated that the results are similar. These results indicated that cnf1 may be a specific marker for virulent strains, especially for the urinary tract and sepsis-related ExPEC.

In our study, contrary to $\mathbf{c n f} 1$ (56\%), cnf2 with a rate of $7,6 \%$ and $\mathbf{c n f} 3$ with a rate of $16 \%$ were found less (Table 4 ). This can be explained by the fact that cnf2 and cnf3 are of animal origin and are rare in human beings. However, as opposed to other studies, prevalence of $\mathbf{c n f} 2$ and $\mathbf{c n f} 3$ was high in our study $(222,233,241,242,243)$. This rate may represent the prevalence closer to reality, which was also due to the high number of strains.

Phylogenetic analysis revealed that natural $E$. coli isolates were divided into four main phylogenetic groups: A, B1, B2 and D. With using a simple and fast phylogenetic grouping technique triplex PCR (9), the group being mostly associated with virulence was B2 with a rate of $60 \%$ among 156 ExPEC strains having at least one virulence gene. This was followed by group D with a rate of $30 \%$. The rates for the groups A and B1 were $5.1 \%$ and $3.2 \%$, respectively (Table 6). Considering other studies, it can be claimed that ExPEC originated predominantly from phylogroup B2 and group D to a less extent (230-229-224-248-242-222). However, in the study carried out by Bozcal et al., these rates were D (38.14\%), A (29.89\%), B2 (20.61\%) and B1 (11.34\%) in ExPEC isolates isolated from blood samples. The reason for this difference may be the high number of samples in this study, the diversity of our clinical materials (such as urine, blood, wound, sputum, aspirate etc.) and different regions. In our study, in CNF-CDT positive strains; the PFGE method was used to reveal whether $E$. coli strains evolved from deletion, recombination mutations or evolved from an ancestor strain and acquired the ExPEC feature. In determining phylogenetic relationships of 156 strains known to be ExPEC, based on $80 \%$ similarity in the whole genome DNA fragment polymorphism analysis with Xbal-PFGE, it was observed that the test isolates were distributed in 106 large clusters, the largest of which was 5-membered (Fig. 8). ExPEC isolates with the same phylogenetic properties may have different virulence characteristics (Fig. 9). ExPEC isolates isolated from the same patient but from different clinical materials may originate from evolutionarily different ancestors. This may explain that most extraintestinal $E$. coli infections were recovered from the community. Oloomi et al. (249) identified CNF-CDT (+) E. coli strains as highly heterogeneous. In a study conducted by Mora et al. (250) with 59 ExPEC strains, 85\% similarity was taken as basis; 36 of the 59 strains were collected in 12 clusters; however, they found that 23 strains were distributed into single-member clusters and concluded that the Xbal-PFGE profiles of ExPEC isolates, which have recently been shown to move away from a common ancestor, form a homogeneous clonal group based on their significant similarities. Because of the redundancy in the number of clusters and the low rate of similarity between strains, our study may represent the heterogeneity which is closer to reality, resulting from the excess of our strain count.

\section{Conclusion}

The widespread diffusion of the cnf gene in E. coli can help to distinguish ExPEC from commensal strains and these genes can be a specific marker for non-commensal $E$. coli. Especially, cnf- 1 increases the $E$. coli colonization in the urinary system and it can be a characteristic virulence factor for the uropathogenic $E$. coli isolates. The CDT gene family support the colonization of $E$. coli, in extraintestinal areas outside the urinary system. Virulence factors

Page $10 / 26$ 
can be distributed depending on the phylogenetic groups (A, B1, B2, and D) and these phylogroups can be used in separation of pathogen-non pathogen.

Considering the Xbal-PFGE results, the phylogenetic relationships of ExPEC isolates were very weak, so it was inferred that $E$. coli strains can acquire ExPEC feature by acquiring different virulence genes as a result of deletion and recombination mutations under adverse conditions including antibiotic suppression. For this reason, multiple drug resistance may be common among ExPEC strains and this may result in treatment failure. Moreover, infections caused by these strains are more likely to be community-acquired rather than hospital-acquired. In addition, the fact that ExPEC isolates belonging to the same clusters display different virulence characteristics is another indication that these strains are of community origin. The characteristics and spread of virulent ExPEC strains should be monitored by molecular surveillance and limited to vaccine studies.

\section{Abbreviations}

ExPEC; Extraintestinal pathogenic Escherichia coli; PFGE: Pulsed-Field Gel Electrophoresis; CNF: Cytotoxic Necrotizing Factor; CDT: Cytolethal Distending Toxin.

\section{Declarations}

\section{Ethics approval and consent to participate}

This study was carried out with the approval of Çukurova University Faculty of Medicine Non-Interventional Clinical Research Ethics Committee (Date: 10.10.2014 and Decision No: 35-2).

\section{Consent for publication}

Not applicable.

\section{Avaibility of data and materials}

The datasets during and/or analysed during the current study available from the corresponding author on reasonable request.

\section{Competing interests}

The authors declare that they have no competing interests.

\section{Funding}

This study was financially supported by Cukurova University Scientific Research Projects (TDK-2015-3303), Adana, Turkey. The funding body supported the laboratory work. The funding body has no contribution in study design, data analysis, interpretation and in writing of the manuscript. 


\section{Authors' contributions}

COG collected samples, cultured the isolates, and performed DNA extraction, PCR, PFGE. FK and COG designed the study. FK, COG and TN supervised the practical work and data management. COG and FK wrote the manuscript. All authors approved the final version of the manuscript. The authors were written in order.

\section{Acknowledgements}

Not applicable.

\section{References}

1. Kaper, J. B., J. P. Nataro, and H. L. Mobley. Pathogenic Escherichia coli. Nat. Rev. Microbiol. 2004. 2:123-140.

2. Wiles, T. J., R. R. Kulesus, and M. A. Mulvey. Origins and virulence mechanisms of uropathogenic Escherichia coli. Exp. Mol. Pathol. 2008.85:11-19.

3. Nougayr`ede, J. P., S. Homburg, F. Taieb, M. Boury, E. Brzuszkiewicz, G. Gottschalk, C. Buchrieser, J. Hacker, U. Dobrindt, and E. Oswald. Escherichia coli induces DNA double-strand breaks in eukaryotic cells. Science 2006. 313:848-851.

4. Pe'res, S.Y., O. Marches, F. Daig $\leq$, J.P. Nougayrede, F. Herault, C. Tasca, J. De Rycke, and E. Oswald. A new cytolethal distending toxin (CDT) from Escherichia coli producing CNF2 blocks HeLa cell division in G2/M phase. Mol. Microbiol. 1997. 24:1095-1107.

5. Hacker, J., U. Hentschel, and U. Dobrindt. Prokaryotic chromosomes and disease. Science 2003. 301:790-793.

6. AL-zuwainy, J. Abid* Using of astA and uidA Genes Characterization in Detection of Escherichia coli

Prevalence from Human Gallstone International Journal of Science and Research (IJSR) ISSN (Online): August 2014 2319-7064 Volume 3 Issue 8.

7. Tóth I, Hérault F, Beutin L, Oswald E Production of cytolethal distending toxins by pathogenic Escherichia coli strains isolated from human and animal sources: establishment of the existence of a new cdt variant (Type IV). J Clin Microbiol (2003). 41: 4285-4291.

8. Dubois D, Delmas J, Cady A, Robin F, Sivignon A, et al. Cyclomodulins in urosepsis strains of Escherichia coli. J Clin Microbiol (2010). 48: 2122-212. 30.

9. Clermont O, Bonacorsi S, Bingen E. Rapid and simple determination of the Escherichia coli phylogenetic group. Appl Environ Microbiol 2000; 66: 4555-4558.

10. Guven Gokmen T, Akcimen B, Kayar B, Marzi M, Koksal F. The outbreak of Acinetobacter baumannii producing OXA-23 and OXA-51 type carbapenemases in a state hospital. J. Exp. Clin. Med., 2016; 33(3): 157-161.

11. Bozcal E. Distribution and virulence properties of extra-intestinal pathogenic Escherichia coli in Turkey. Microbiologia Medica 2016; 31:6324.

12. Johnson,J.R., K.Owens, A.Gajewski,and M.A.Kuskowski..Bacterial characteristics in relation to clinical source of Escherichia coli isolates from women with acute cystitis or pyelonephritis and uninfected women. J. Clin. Microbiol. 2005. 43:6064-6072.

13. Curová K, Kmetová M, Vargová R, Lovayová V, Siegfried L. Toxins of Extraintestinal Escherichia coli Isolated from Blood Culture. Clin Microbial (2014). 3:171. doi: 10.4172/2327-5073.1000171. 
14. López-Banda, D. A., Carrillo-Casas, E. M., Leyva-Leyva, M., Orozco-Hoyuela, G., Manjarrez-Hernandez, ÁH., Arroyo-Escalante, S.,Moncada-Barrón, D., Villanueva-Recillas, S., Xicohtencatl-Cortes, J.\& other authors Identification of virulence factors genes in Escherichia coli isolates from women with urinary tract infection in Mexico.Biomed Res Int 2014, 959206.

15. Pickett, C. L., D. L. Cottle, E. C. Pesci, and G. Bikah. Cloning, sequencing and expression of the Escherichia coli cytolethal distending toxin production genes. Infect. Immun. 62:1046-1051., Scott, D. A., and J. Kaper. 1994. Cloning and sequencing of the genes encoding Escherichia coli cytolethal distending toxin. Infect. Immun. 1994. 62:244- 251.

16. Tóth I, Nougayrède JP, Dobrindt U, Ledger TN, Boury M, et al. Cytolethal distending toxin type I and type IV genes are framed with lambdoid prophage genes in extraintestinal pathogenic Escherichia coli. Infect Immun (2009). 77: 492-500.

17. To'th, I., J. P. Nougayre`de, U. Dobrindt, T. N. Ledger, M. Boury, S. Morabito, T. Fujiwara, M. Sugai, J. Hacker, and E. Oswald. Cytolethal distending toxin type I and type IV genes are framed with lambdoid prophage genes in extraintestinal pathogenic Escherichia coli. Infect. Immun. 2009. 77:492-500.

18. Johnson, J. R., and A. L. Stell. Extended virulence genotypes of Escherichia coli strains from patients with urosepsis in relation to phylogeny and host compromise. J. Infect. Dis. 2000. 181:261-272.

19. Caprioli, A.; Falbo, V.; Roda, L.G.; Ruggeri, F.M.; Zona, C. Partial purification and characterization of an Escherichia coli toxic factor that induces morphological cell alterations. Infect. Immun. 1983, 39, 1300-1306.

20. Landraud L, Gauthier M, Fosse T, Boquet P. Frequency of Escherichia coli strains producing the cytotoxic necrotizing factor (CNF1) in nosocomial urinary tract infections. LettAppl Microbio/ 2000; 30:213-6.

21. Rahman H, Deka M. Detection and characterization of necrotoxin producing Escherichia coli (NTEC) from calves with diarrhoea. JVPH., 2012; 10(2): 97-102.》

22. Koga VL, Tomazetto G, Cyoia PS, Neves MS, Vidotto MC, Nakazato G, et al. Molecular screening of virulence genes in extraintestinal pathogenic Escherichia coli isolated from human blood culture in Brazil. BioMed Res Int. 2014; 2014: 465054.

23. Rippere-Lampe, K.E.; Lang, M.; Ceri, H.; Olson, M.; Lockman, H.A.; O'Brien, A.D. Cytotoxic necrotizing factor type 1-positive Escherichia coli causes increased inflammation and tissue damage to the prostate in a rat prostatitis model. Infect. Immun. 2001, 69, 6515-6519.

24. Hopkins, A.M.; Walsh, S.V.; Verkade, P.; Boquet, P.; Nusrat, A. Constitutive activation of Rho proteins by CNF-1 influences tight junction structure and epithelial barrier function. J. Cell Sci. 2003, 116, 725-742.

25. Hofmann, P.; Le Negrate, G.; Mograbi, B.; Hofmann, V.; Brest, P.; Alliana-Schmid, A.; Flatau, G.; Boquet, P.; Rossi, B. Escherichia coli cytotoxic necrotizing factor-1 (CNF-1) increases the adherence to epithelia and the oxidative burst of human polymorphonuclear leukocytes but decreases bacteria phagocytosis. J. Leukoc. Biol. 2000, 68, 522-528.

26. Doye, A.; Mettouchi, A.; Bossis, G.; Clément, R.; Buisson-Touati, C.; Flatau, G.; Gagnoux, L.; Piechaczyk, M.; Boquet, P.; Lemichez, E. CNF1 exploits the ubiquitin-proteasome machinery to restrict Rho GTPase activation for bacterial host cell invasion. Cell 2002, 111, 553-564.

27. Miraglia, A.G.; Travaglione, S.; Meschini, S.; Falzano, L.; Matarrese, P.; Quaranta, M.G.; Viora, M.; Fiorentini, C.; Fabbri, A. Cytotoxic necrotizing factor 1 prevents apoptosis via the Akt/lkappaB kinase pathway: role of nuclear factor-kappaB and Bcl-2. Mol. Biol. Cell 2007, 18, 2735-2744. 
28. Falzano, L.; Fiorentini, C.; Donelli, G.; Michel, E.; Kocks, C.; Cossart, P.; Cabanié, L.; Oswald, E.; Boquet, P. Induction of phagocytic behaviour in human epithelial cells by Escherichia coli cytotoxic necrotizing factor type 1. Mol. Microbiol. 1993, 9, 1247-1254.

29. Ananias, M.; Yano, T. Serogroups and virulence genotypes of Escherichia coli isolated from patients with sepsis. Braz. J. Med. Biol. Res. 2008, 41, 877-883.

30. Kadhum, H.J.; Fınlay, D.; Rowe, M.T.; Wılson, I.G. \& Ball, H.J. - Occurrence and characteristics of cytotoxic necrotizing factors, cytolethal distending toxins and other virulence factors in Escherichia coli from human blood and faecal samples. Epidem. Infect., 2008. 136: 752-760.

31. Lopez-Banda DA, Carrillo-Casas EM, Leyva-Leyva M, Orozco-Hoyuela G, Manjarrez-Hernandez AH, ArroyoEscalante $S$, et al. Identification of virulence factors genes in Escherichia coli isolates from women with urinary tract infection in Mexico. Biomed Res Int. 2014:959206.

32. Bozcal E., Eldem V., Aydemir S., Skurnik M. The relationship between phylogenetic classification, virulence and antibiotic resistance of extraintestinal pathogenic Escherichia coli in İzmir province, Turkey. 2018 PeerJ, DOI $10.7717 /$ peerj. 5470

33. Kadhum H. J., Ball H. J., Oswald E., Rowe M. T. Characteristics of cytotoxic necrotizing factor and cytolethal distending toxin producing Escherichia coli strains isolated from meat samples in Northern Ireland. Food Microbiol. (2006). 23, 491-497 10.1016/j.fm.2005.07.003.

34. Giray B, Uçar FB, Aydemir SS. Genotypic analysis of Escherichia coli strains that cause urosepsis in the Aegean region. Turk J Med Sci. 2016; 46:1-10.

35. Oloomi M, Bouzari S. Molecular profile and genetic diversity of cytolethal distending toxin (CDT)-producing Escherichia coli isolates from diarrheal patients. APMIS. 2008; 116:125-32.

36. Mora A, Lopez C, Dabhi G, Blanco M, Blanco JE, Alonso MP, Herrera A, Mamani R, Bonacorsi S, MolulinSchouleur M et al. Extraintestinal pathogenic Escherichia coli 01:K1:H7/ NM from human and avian origin: detection of clonal groups B2 ST95 and D ST59 with different host distribution. BMC Microbiol 2009; 9: 1-11.

\section{Figures}

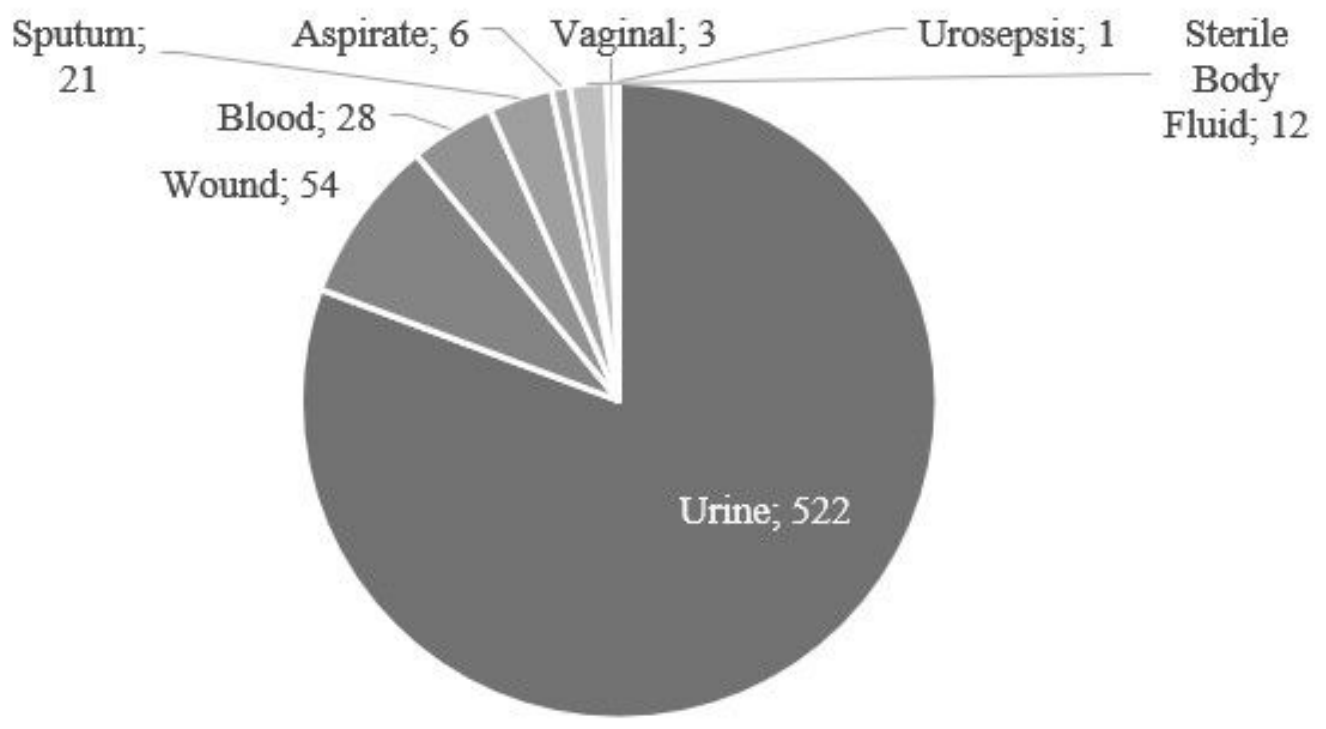

Figure 1

Page $14 / 26$ 
Distribution of isolates by clinical origin

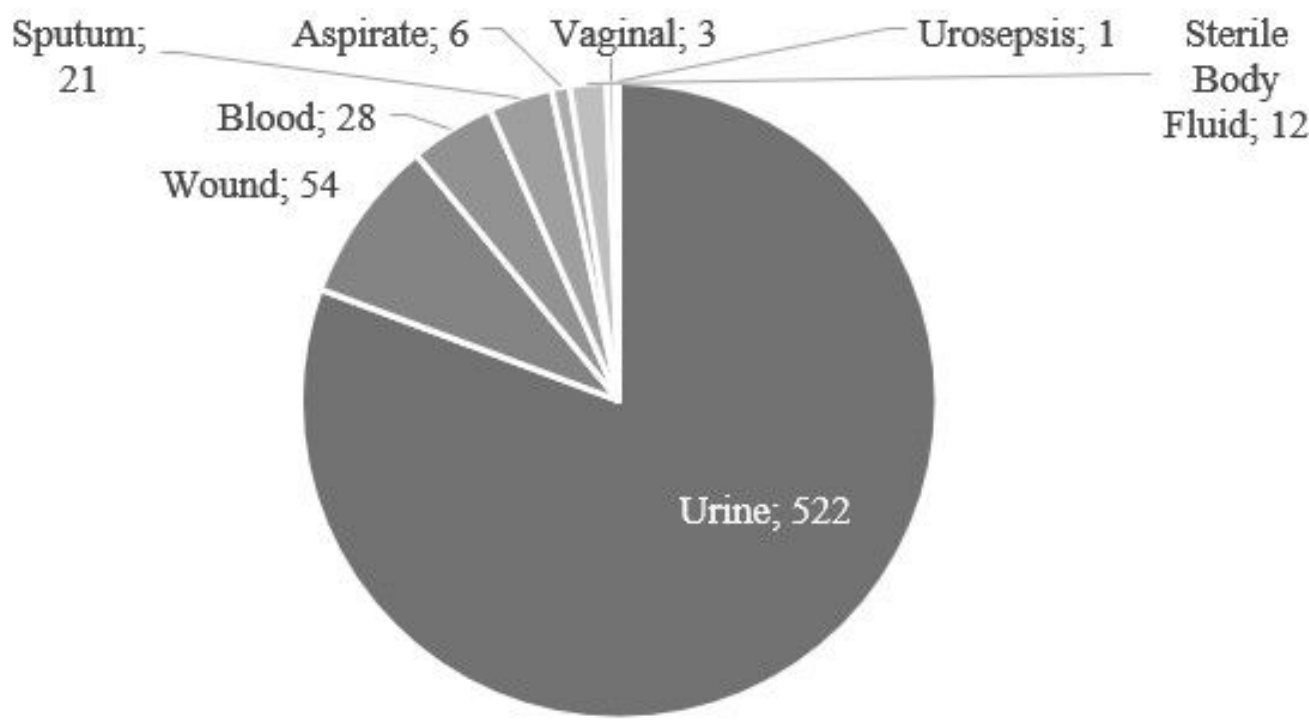

\section{Figure 1}

Distribution of isolates by clinical origin

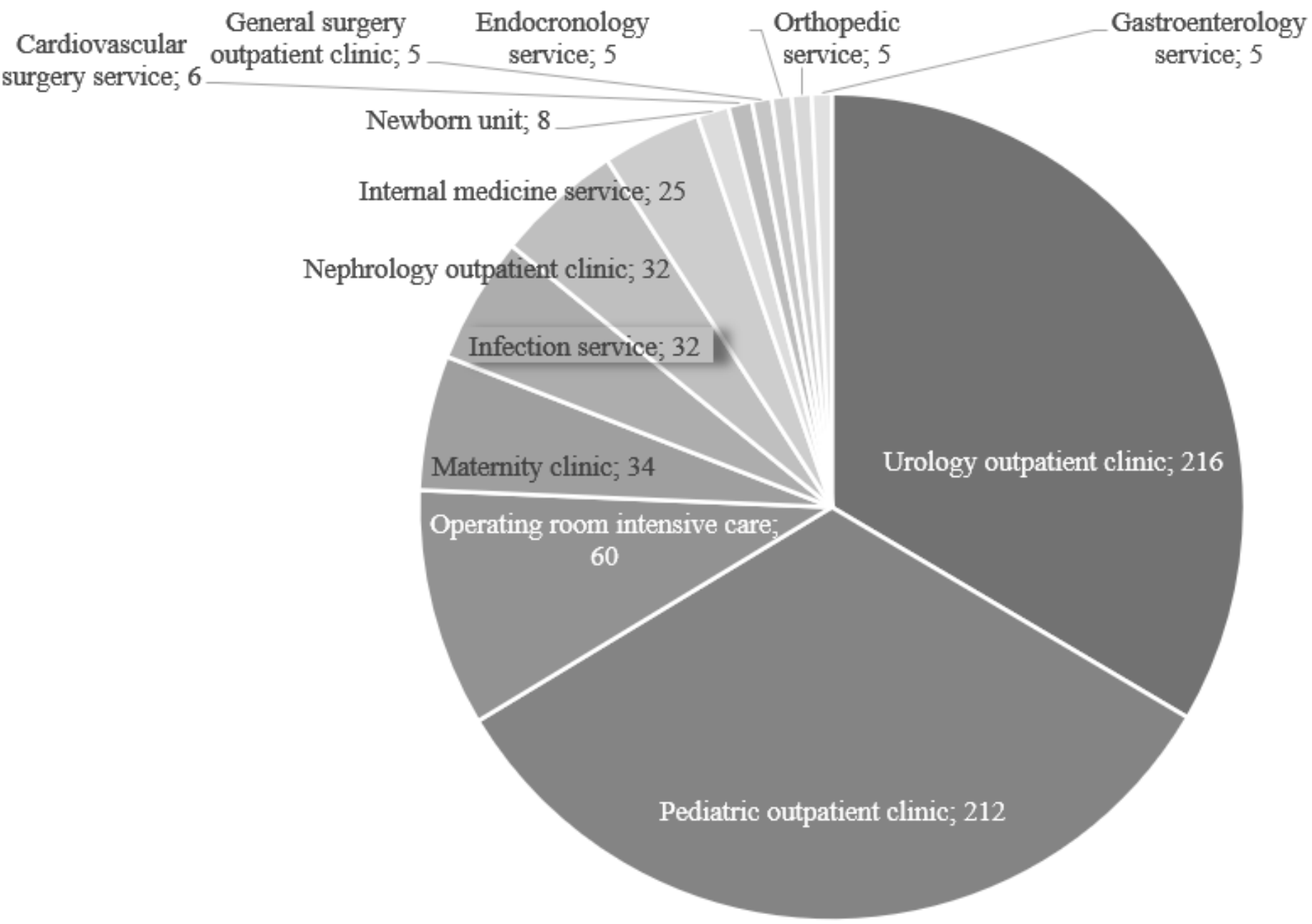

Figure 2 
Distribution of 645 ExPEC isolates by Clinic and Polyclinics

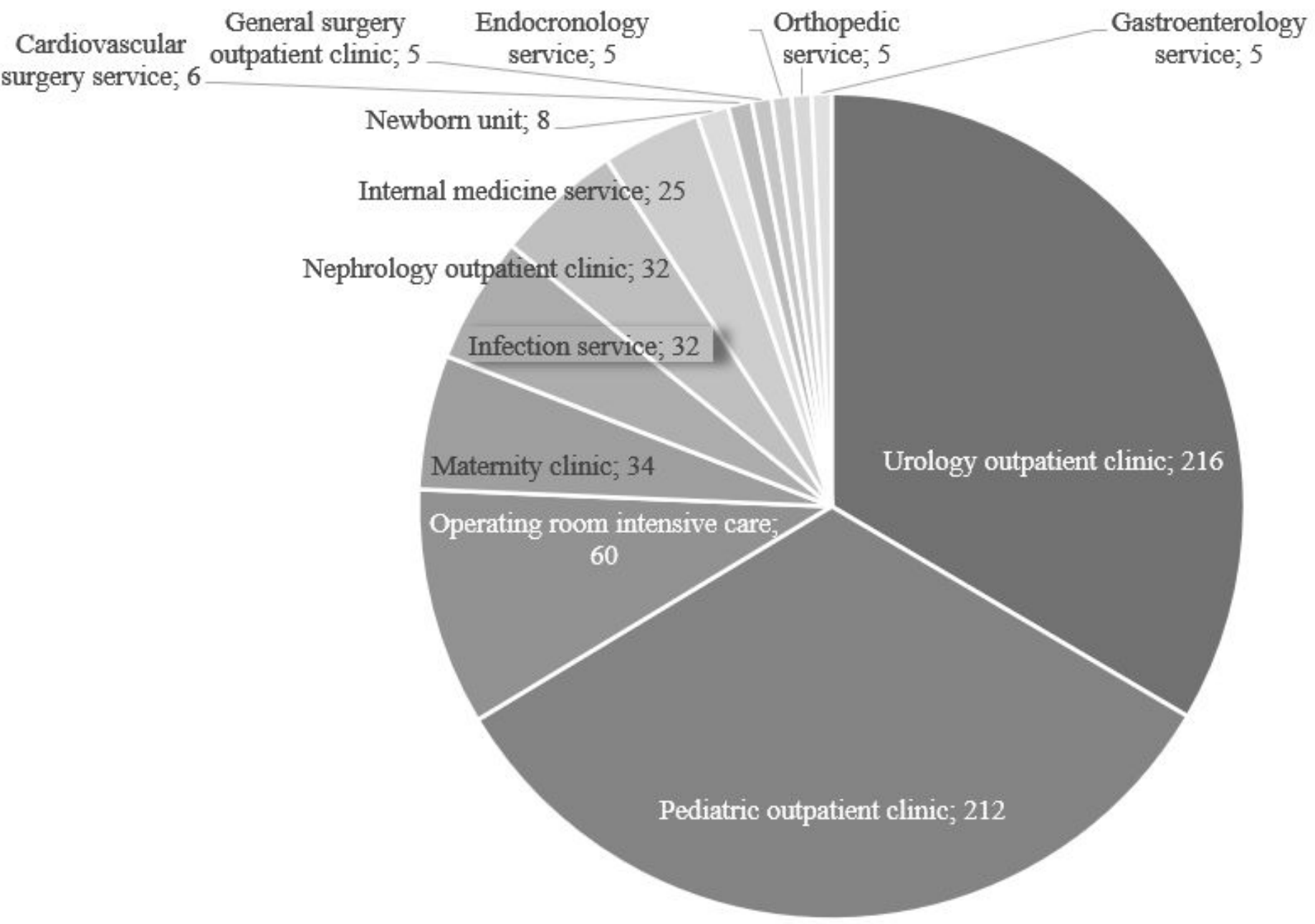

\section{Figure 2}

Distribution of 645 ExPEC isolates by Clinic and Polyclinics

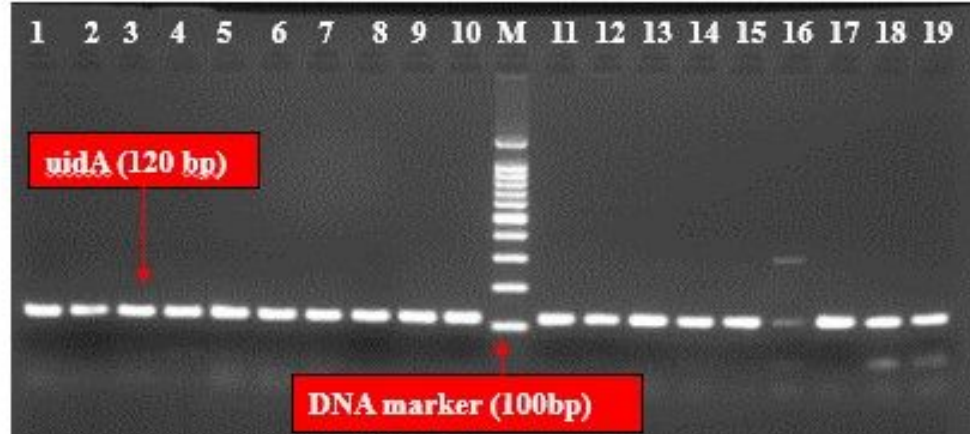

$\begin{array}{llllll}20 & 21 & 22 & 24 & 25 & 26 \\ \mathrm{M}\end{array}$

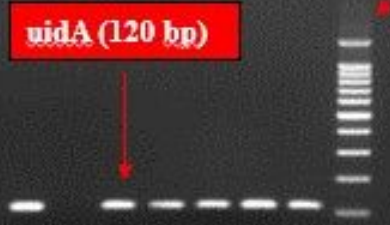




\section{Figure 3}

Gel image showing the band profile of the uidA genes region

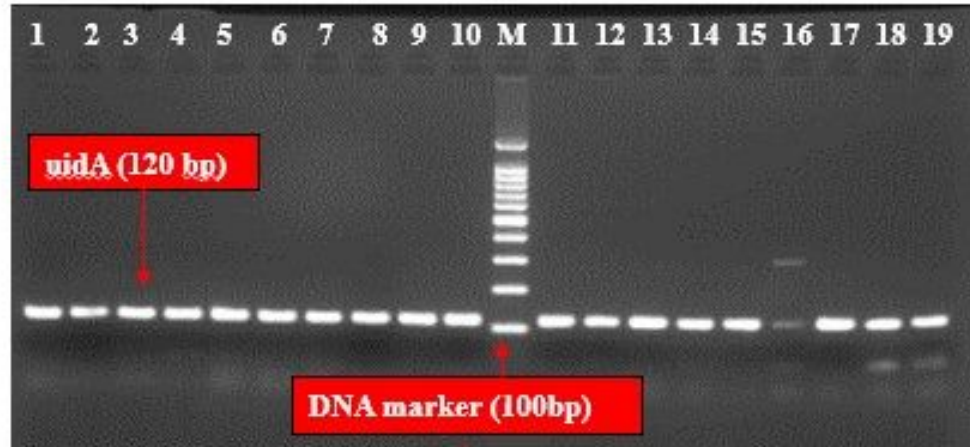

$20 \quad 2122 \quad 23242526$ M

uidA (120 bp)

\section{Figure 3}

Gel image showing the band profile of the uidA genes region

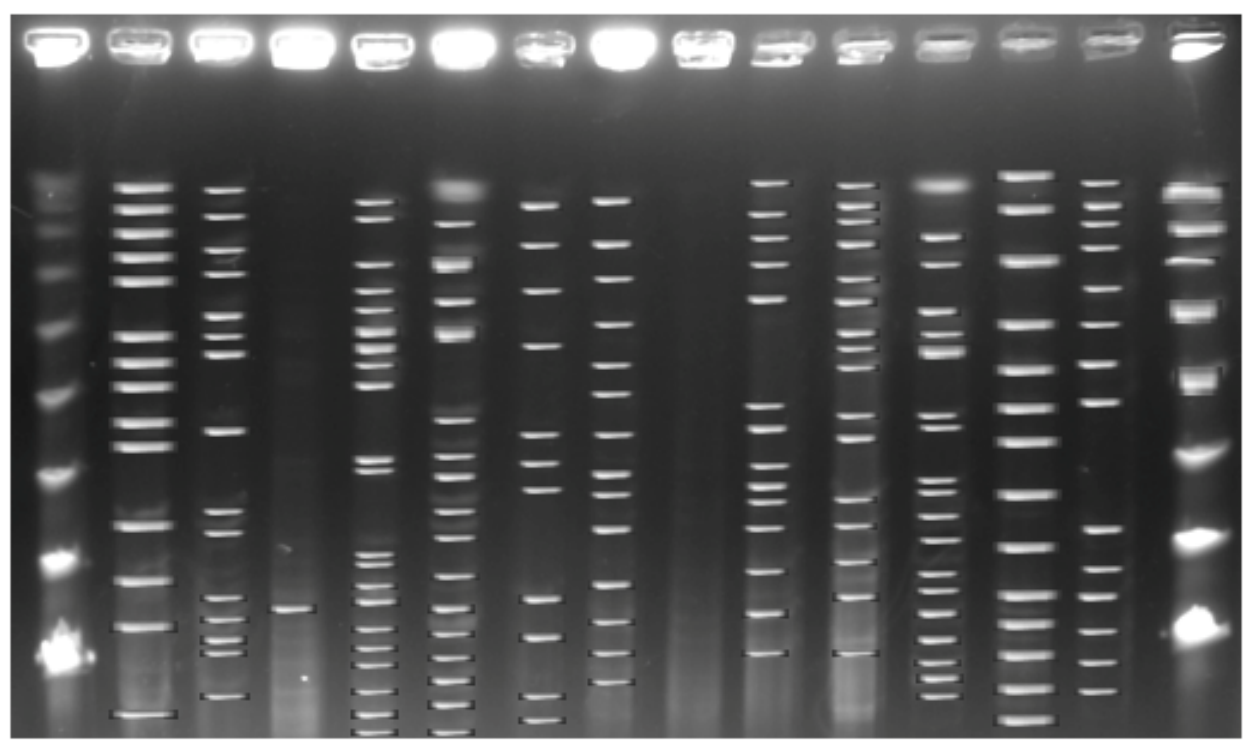

Figure 4

PFGE Resulting Band Profiles 


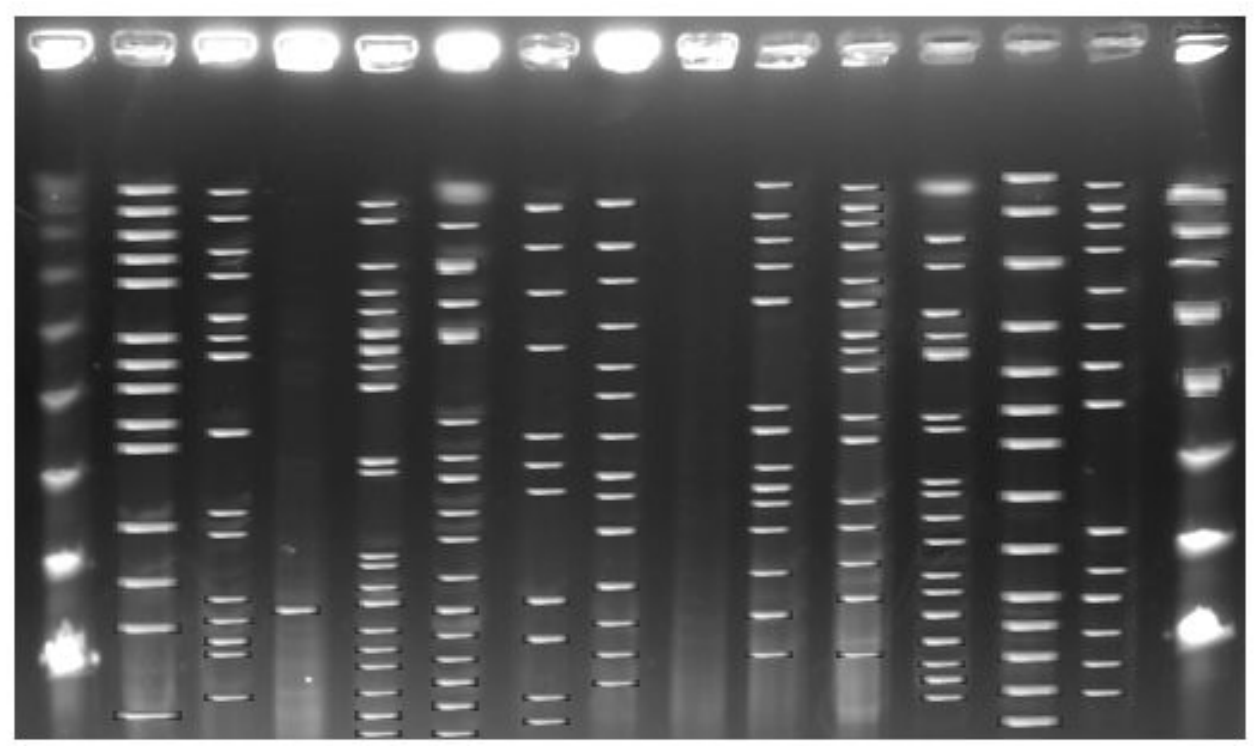

Figure 4

PFGE Resulting Band Profiles 


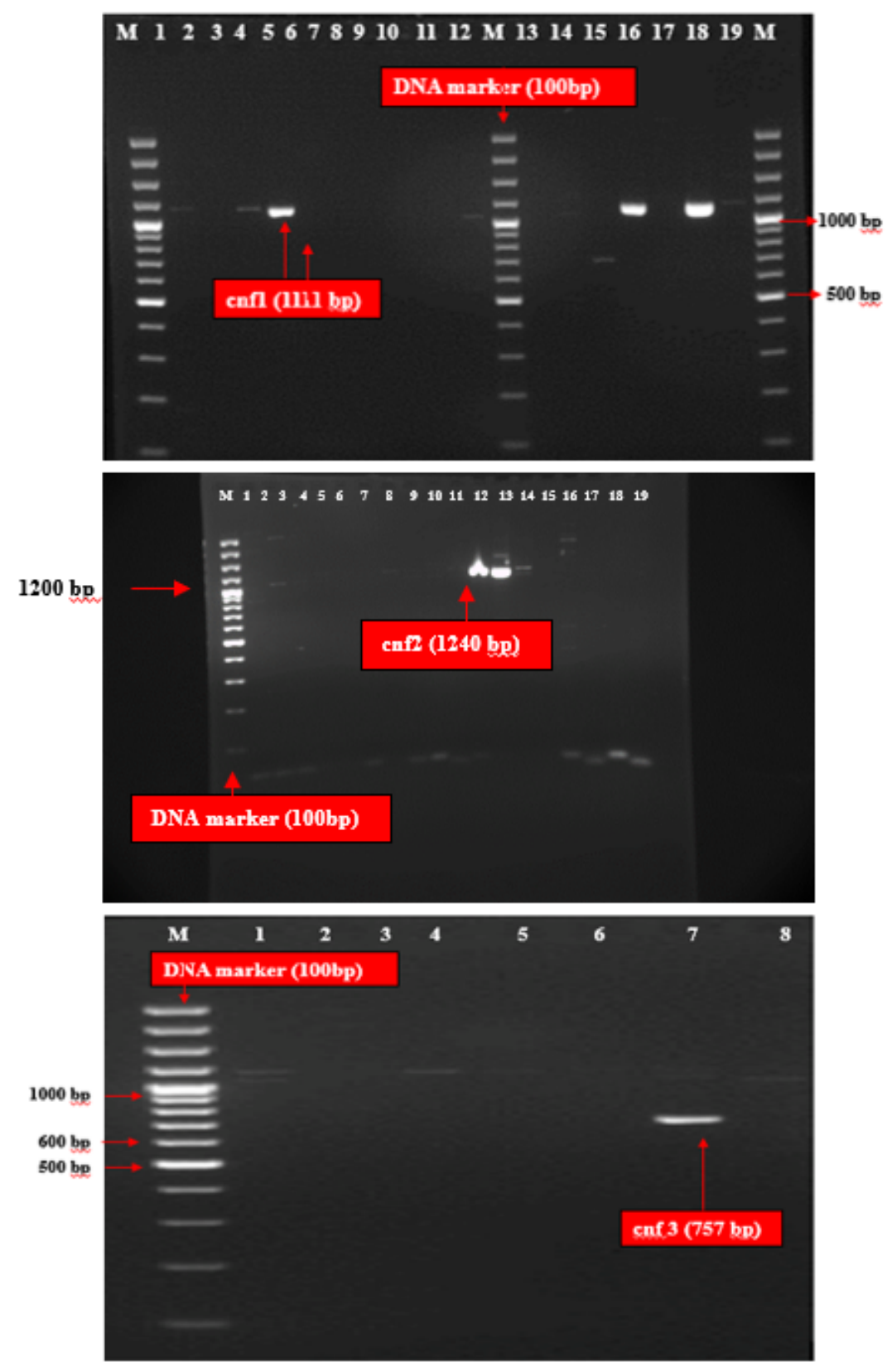

Figure 5

Gel image showing the band profile of the CNF genes region 


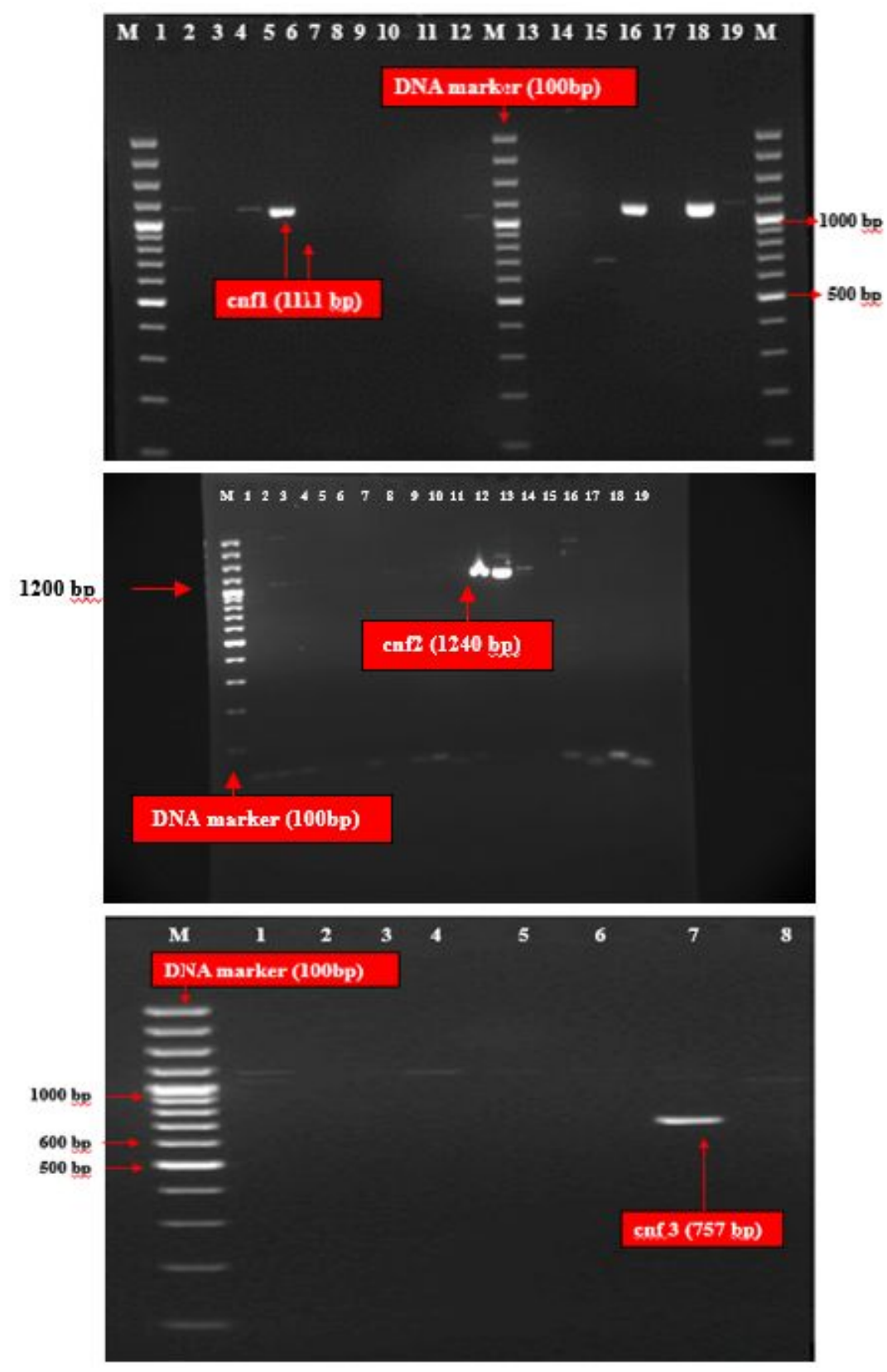

Figure 5

Gel image showing the band profile of the CNF genes region 


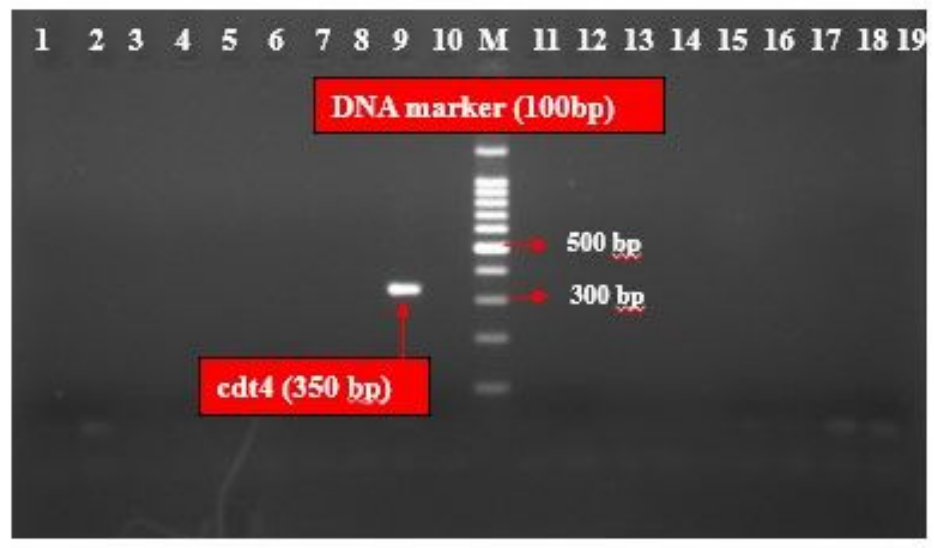

\section{Figure 6}

Gel image showing the band profile of the CDT genes region

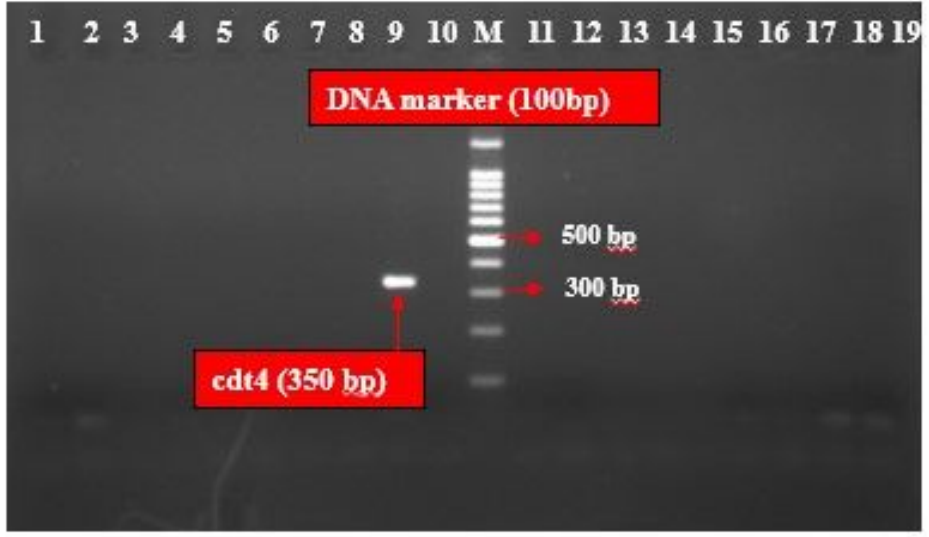

Figure 6

Gel image showing the band profile of the CDT genes region 


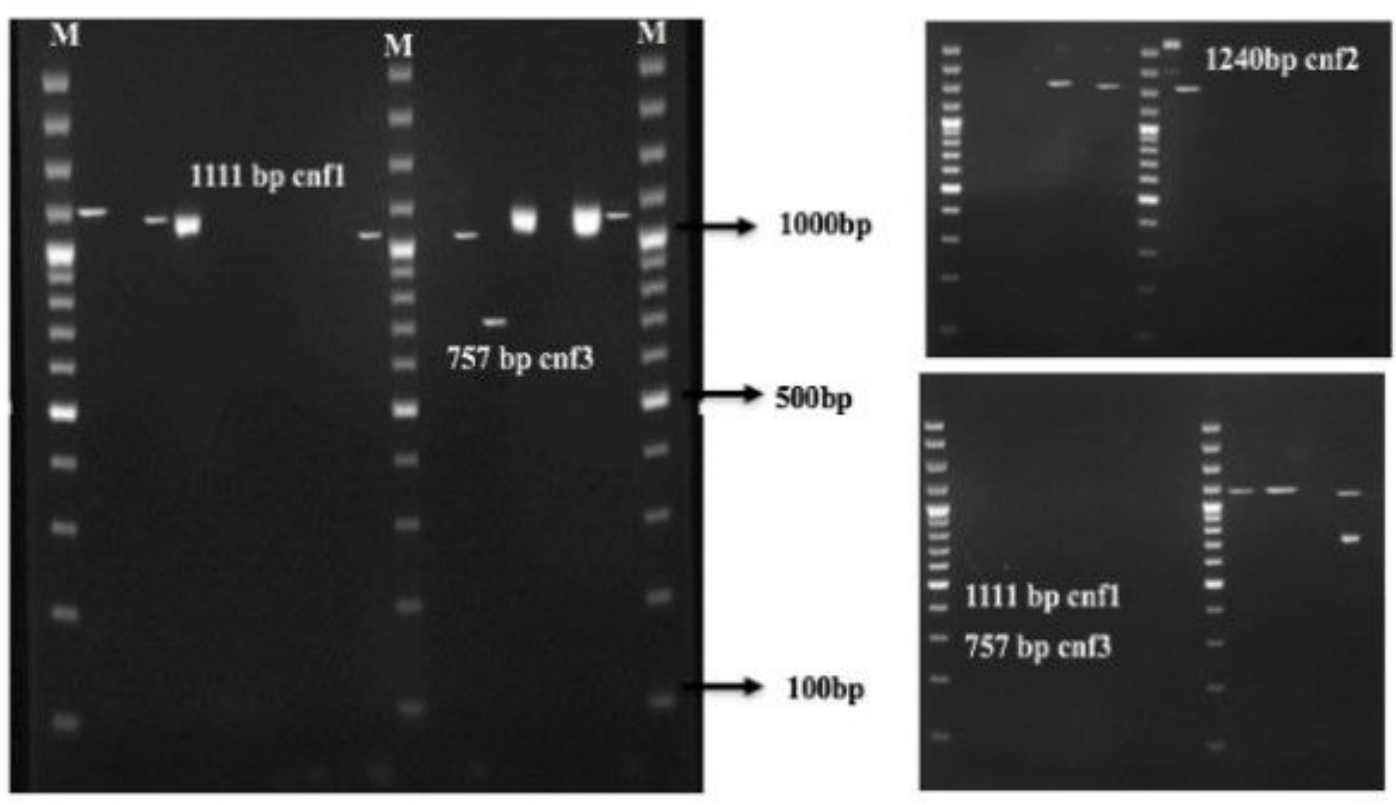

\section{Figure 7}

Gel image showing the band profile of the both toxin-factor genes region

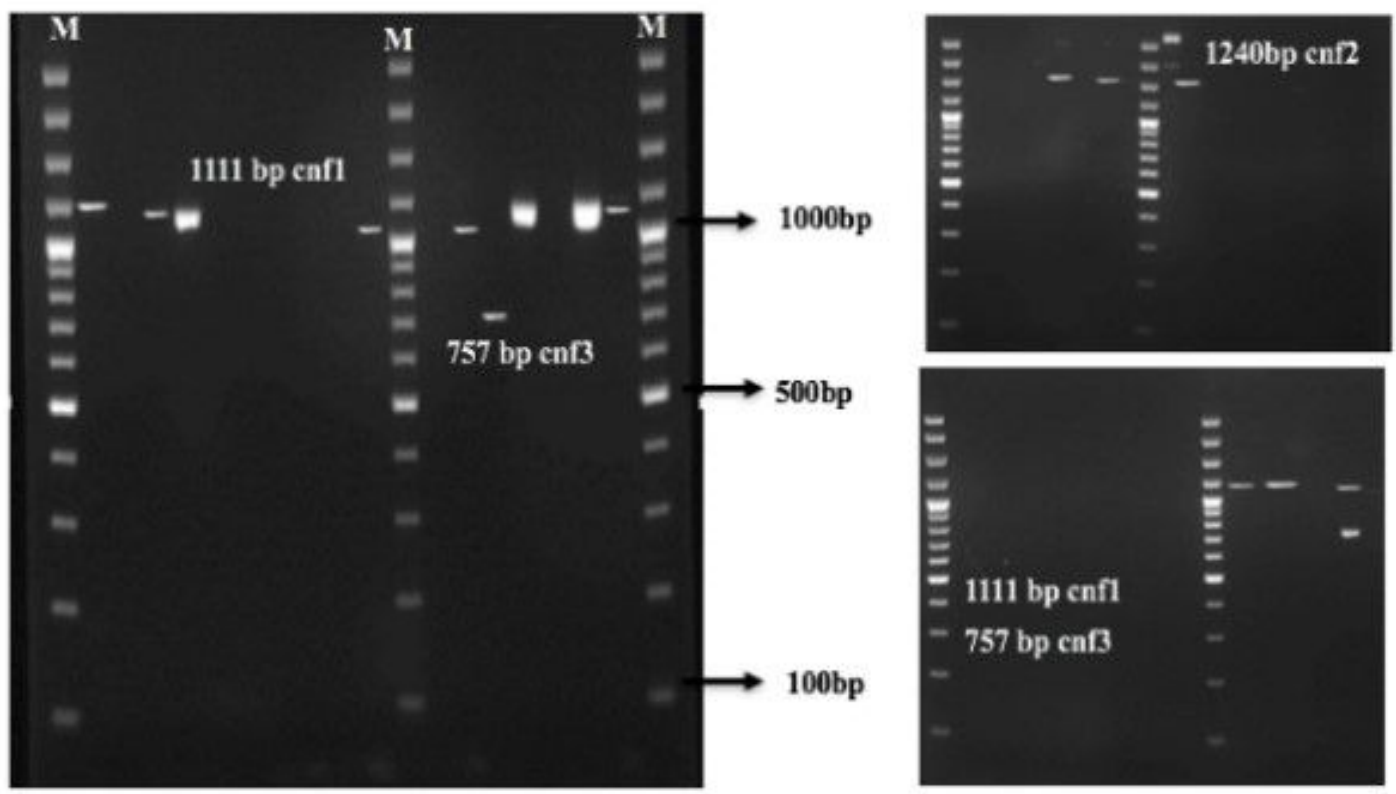

Figure 7

Gel image showing the band profile of the both toxin-factor genes region 


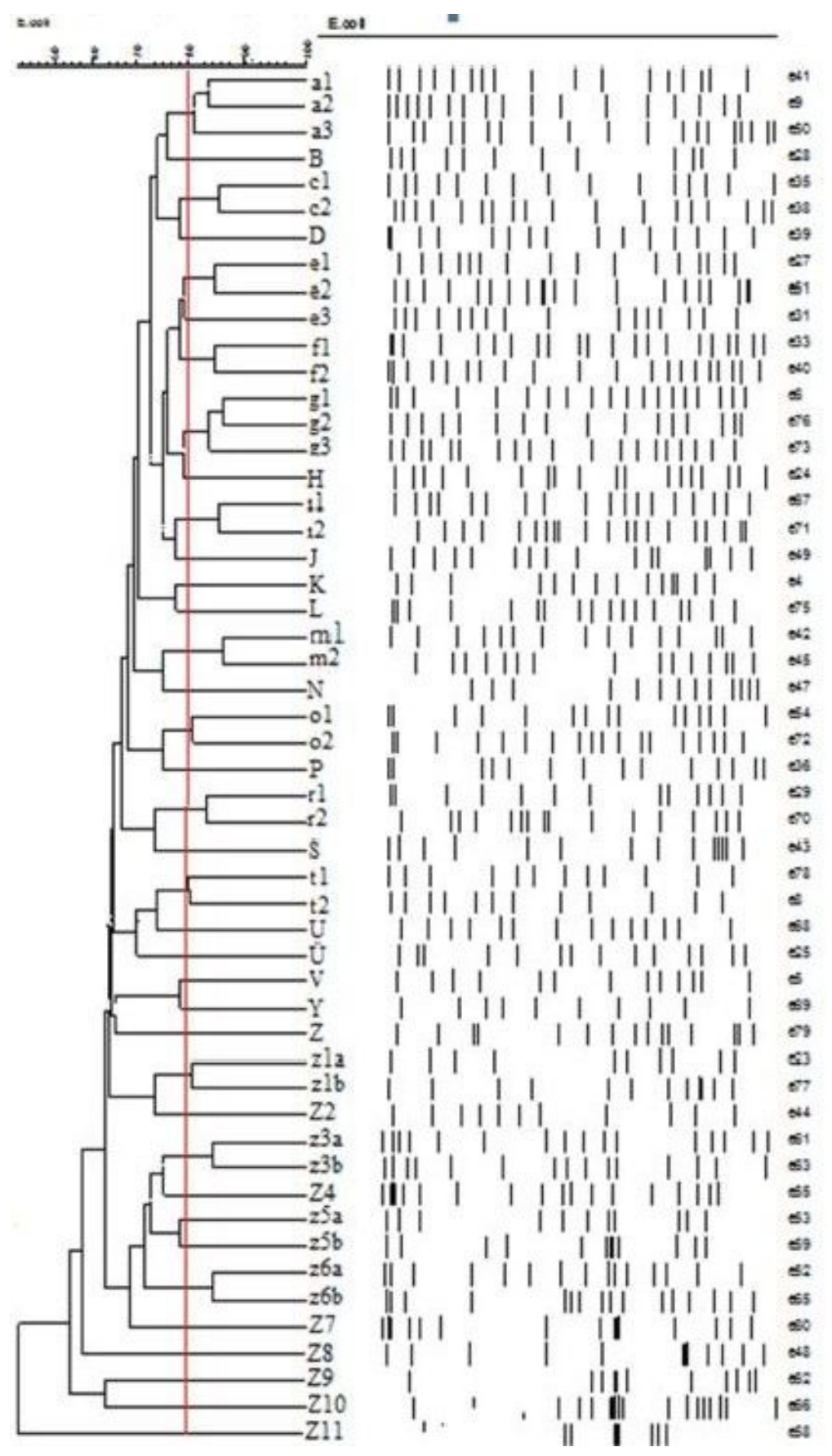

Figure 8

Dendrogram with PFGE Result 


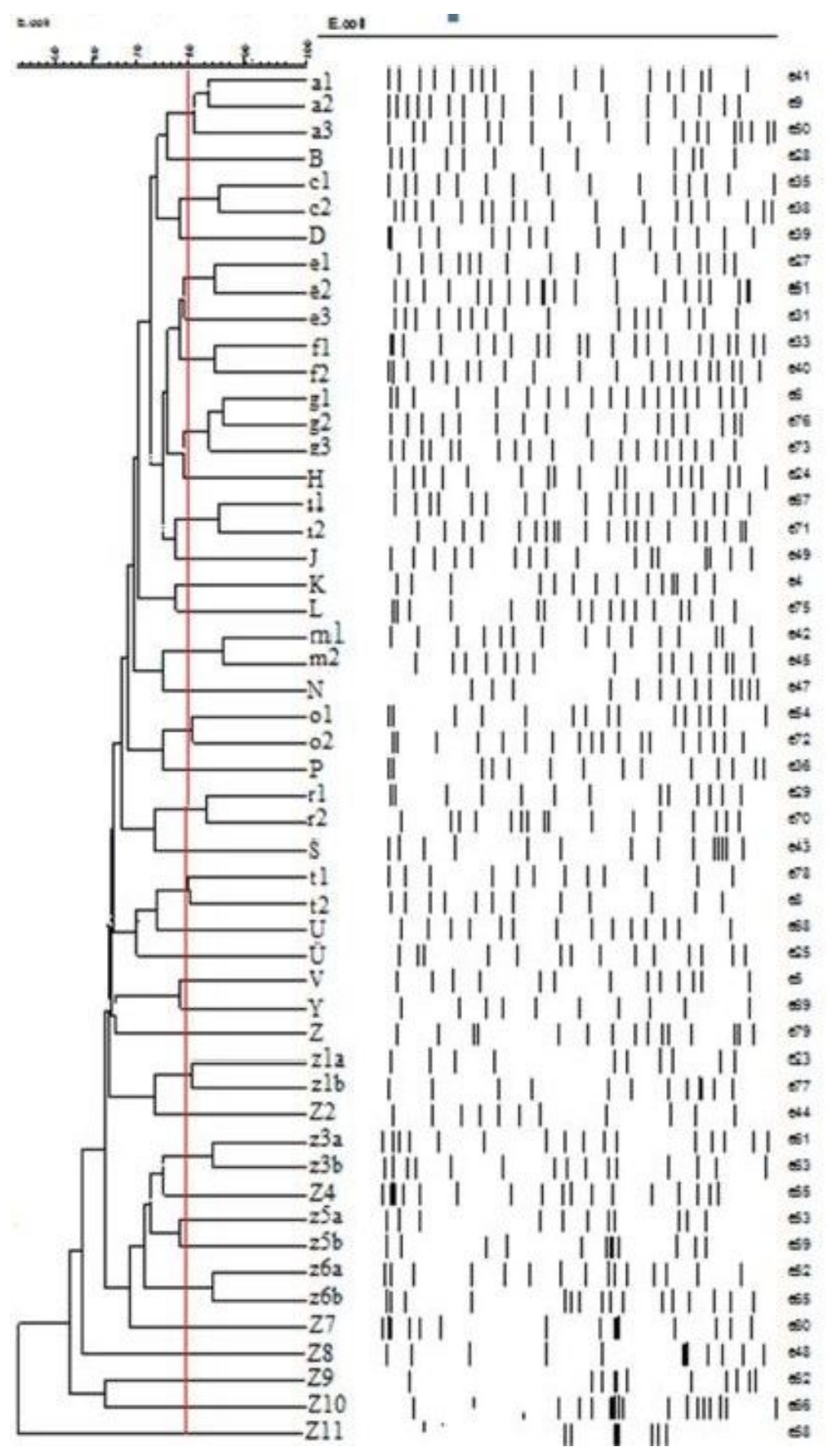

Figure 8

Dendrogram with PFGE Result 


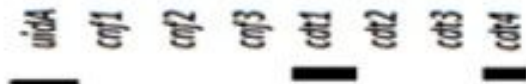

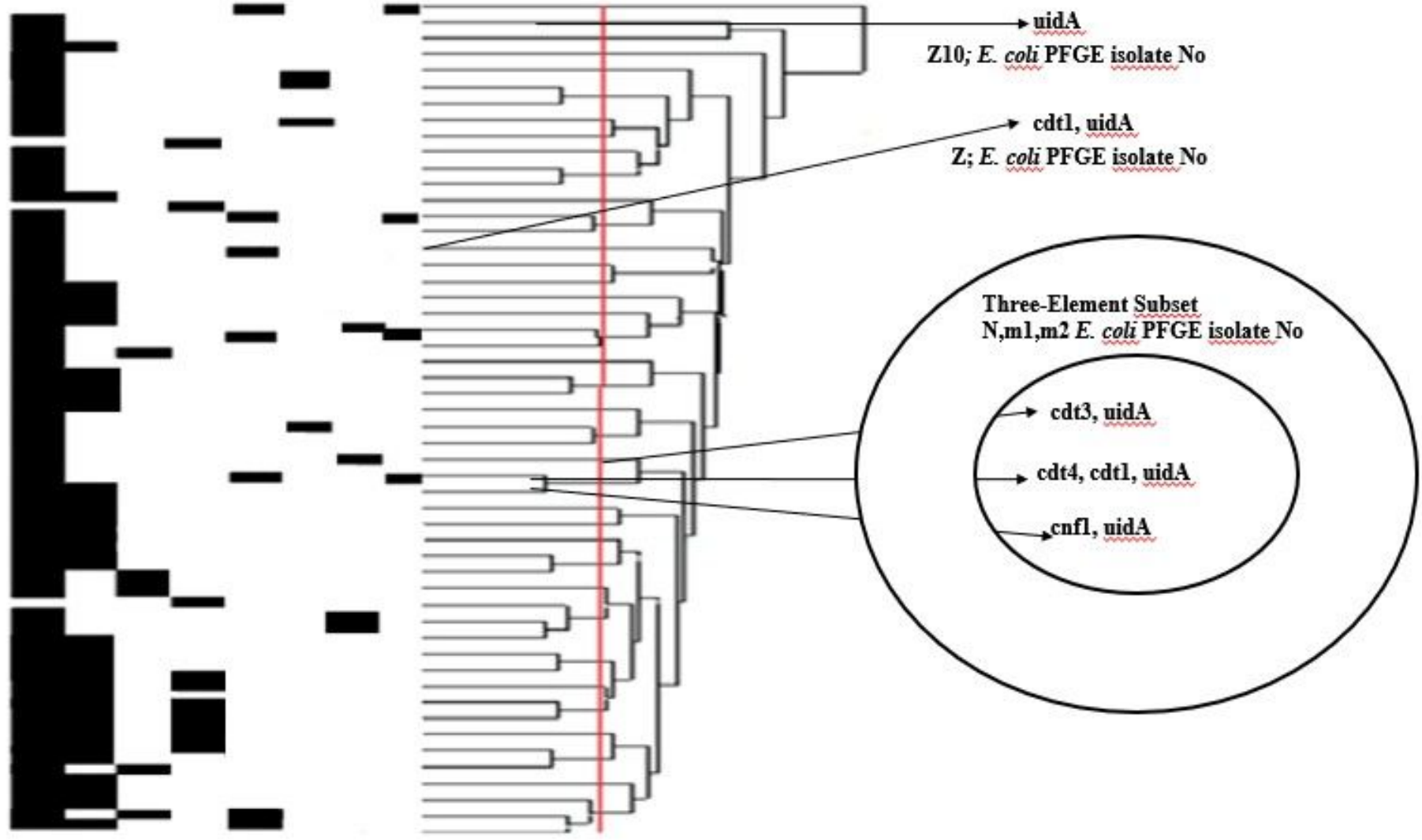

Figure 9

Clustering of virulence genotyping 


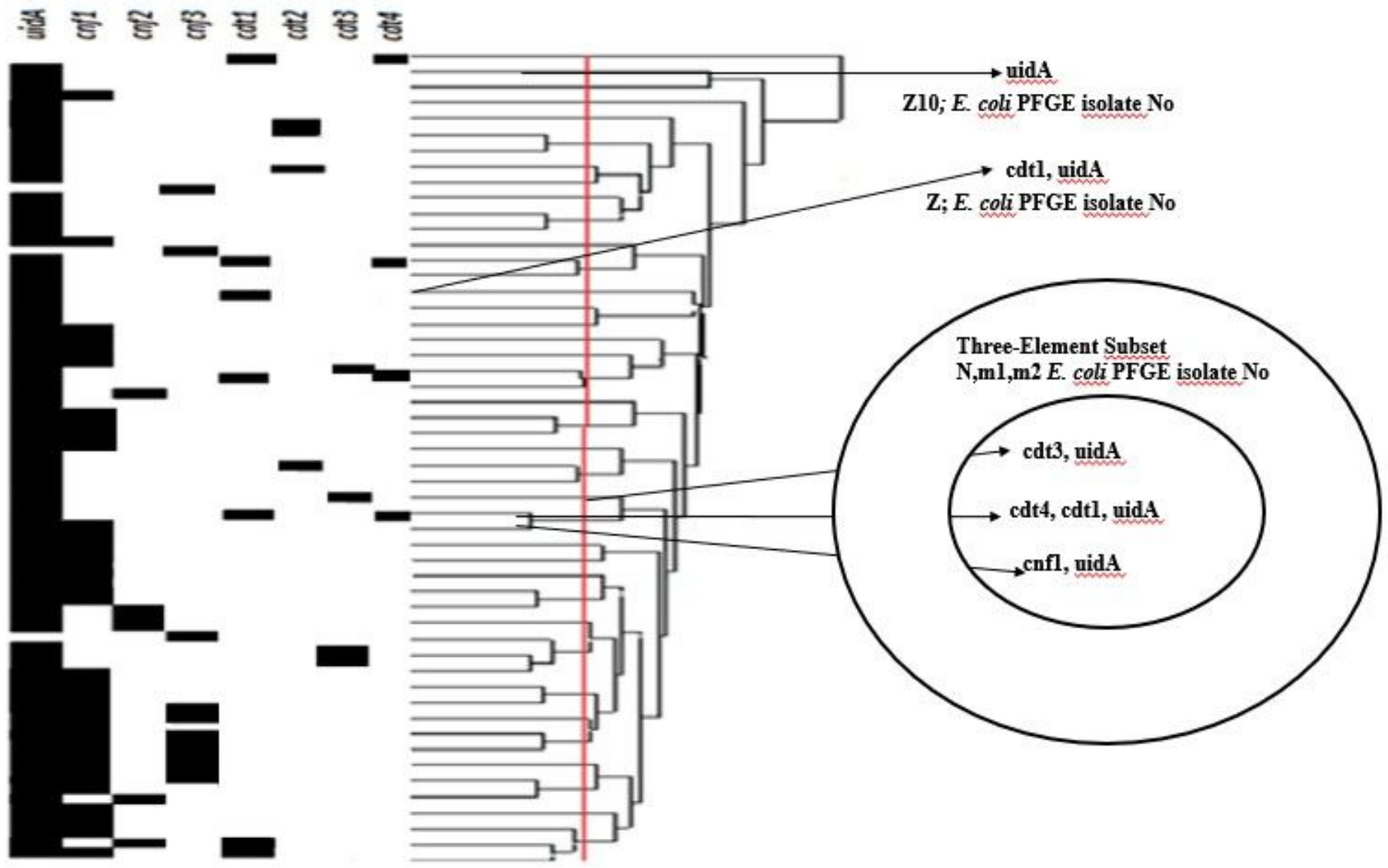

Figure 9

Clustering of virulence genotyping

\section{Supplementary Files}

This is a list of supplementary files associated with this preprint. Click to download.

- SupplementeryDocument.docx

- SupplementeryDocument.docx 